\title{
ARTRÓPODOS (PERJUDICIALES Y BENÉFICOS) Y MALEZAS EN EL PRIMER AÑO DE IMPLANTACIÓN DE ALFALFA, EN LA PROVINCIA SAN LUIS
}

\author{
Bonivardo, S. L. ${ }^{1 ;}$ Martinez, A. N. ${ }^{1}$; Basconcello, J. ${ }^{1}$; \\ Bosco, A. ${ }^{1}$ \& Pérez Quinteros, M. $^{1}$
}

\begin{abstract}
RESUMEN
La alfalfa es la especie forrajera base de la producción de carne y de leche en la Región Pampeana. Su establecimiento, productividad y persistencia, dependen de numerosos factores, entre los cuales figuran los relacionados con la sanidad del cultivo en su primer año de implantación. Con la finalidad de conocer las especies perjudiciales (insectos y malezas) y especies benéficas (artrópodos) y sus poblaciones, es que se consideró importante el presente estudio. Los resultados obtenidos en cuanto a diversidad, niveles poblacionales de artrópodos y cobertura de malezas, según las técnicas de muestreo recomendadas para cada caso, permiten conocer para la zona centro este de la provincia de San Luis, las especies que pueden comportarse como potenciales plagas y controladores bilógicos. Junto con prácticas de manejo constituyen herramientas del manejo integrado de problemas fitosanitarios del cultivo.

Palabras Claves: Alfalfa; fitófagos; malezas; enemigos naturales; manejo.
\end{abstract}

\begin{abstract}
Arthropods (harmful and beneficial) and weeds in the first year of implementation of alfalfa in san luis province.

Alfalfa is the forage species based on the production of meat and milk in the Pampas. Its establishment, productivity and persistence, depend on many factors, among which are those related to the health of the crop in the first year of implementation. In order to know the harmful species (insects and weeds) and beneficial species (arthropods), and their populations, it is that this study was considered important. The results obtained in terms of diversity, population levels of arthropods and weed cover, according to the techniques recommended for each sample, provide insight for this center area of the province of San Luis, species that may act as potential pests and bilógicos controllers. Together with management practices are tools of integrated management of phytosanitary problems of the crop.

Key Words: Alfalfa; insect pests; weeds, natural enemies.
\end{abstract}

1.- Proyecto C y T - UNSL No 140512 Dpto. Cs. Agropecuarias. Facultad de Ingeniería y Cs. Agropecuarias (FICA). UNSL. Av. 25 de Mayo 384. Villa Mercedes, provincia de San Luis. Email: sbonivardo@gmail.com Manuscrito recibido el 27 de julio de 2015 y aceptado para su publicación el 22 de febrero de 2016. 